\title{
Thyroid hormone resistance in two patients with papillary thyroid microcarcinoma and their BRAFV600E mutation status
}

1 Diskapi Yildirim Beyazit Training and Research Hospital, Department of Endocrinology and Metabolism, Ankara, Turkey ${ }^{2}$ Diskapi Yildirim Beyazit Training and Research Hospital, Department of Stem Cell and Genetic

Diagnostic Center, Ankara, Turkey Hacettepe University, School of Medicine (Kastamonu), Department of Internal Medicine, Ankara, Turkey

\section{Correspondence to:}

Melia Karakose

Diskapi Hospital,

Irfan Bastug Caddesi,

Ankara, Turkey

meliakarakose@yahoo.com.tr

Received on May/16/2014

Accepted on Nov/24/2014

DOI: 10.1590/2359-399700000009
Melia Karakose', Mustafa Caliskan', Muyesser Sayki Arslan', Erman Cakal', Ahmet Yesilyurt², Tuncay Delibasi ${ }^{1,3}$

\begin{abstract}
SUMMARY
Resistance to thyroid hormone (RTH) is a rare autosomal dominant hereditary disorder. Here in, we report two patients with RTH in whom differentiated thyroid cancer was diagnosed. Two patients were admitted to our clinic and their laboratory results were elevated thyroid hormone levels with unsuppressedTSH. We considered this situation thyroid hormone resistance in the light of laboratory and clinical datas. Thyroid nodule was palpated on physical examination. Thyroid ultrasonography showed multiple nodules in both lobes. Total thyroidectomy was performed. The pathological findings were consistent with papillary thyroid microcarcinoma. BRAFV600E mutation analysis results were negative. RTH is very rare and might be overlooked. There is no consensus on how to overcome the persistently highTSH in patients with RTH and differentiated thyroid cancer (DTC). Further studies are needed to explain the relationship between RTH and DTC which might be helpful for the treatment of these patients. Arch Endocrinol Metab. 2015;59(4):364-6
\end{abstract}

\section{INTRODUCTION}

$\mathrm{R}$ esistance to thyroid hormone (RTH) is a rare autosomal dominant hereditary disorder characterized by a reduced responsiveness of the pituitary and peripheral target tissues to thyroid hormone $(1,2)$. RTH is caused by mutations in the thyroid hormone receptor beta $($ THR $\beta)$ gene $(1,2)$. The incidence of RTH is unknown and both sexes affected equally by RTH (3). Patients with RTH have elevated serum free thyroxine (fT4) and free triiodothyronine (fT3) concentrations with nonsuppressed TSH secretion. Despite a variable clinical presentation, the common characteristic clinical features are goitre but absence of the usual symptoms and metabolic consequences of thyroid hormone excess.

Patients with RTH have an increased risk of developing autoimmune thyroid diseases (4). There are few case reports that describe RTH with papillary thyroid carcinoma (PTC) in the literature $(5,6)$. PTC is the most common form of differentiated thyroid carcinoma (DTC) (7). Total thyroidectomy is applied in the treatment of these patients. However, adjuvant therapy in the form of radioactive iodine (RAI) is often administered as a means of reducing the risk of tumor recurrence (8). After than levothyroxine is used to suppress TSH release in order to prevent the relapse or progression of the residual thyroid cancer (9). TSH suppression may not be obtained despite increasing doses of levothyroxine in a patient with RTH. There is no consensus on how to overcome the persistently high TSH in patients with RTH and DTC. Herein we describe two patients with RTH in whom DTC was diagnosed.

\section{CASE REPORTS}

\section{Case 1}

A 56-year-old Turkish women was referred to internal medicine because of the detection of multinodular goiter in physical examination. Subtotal thyroidectomy was performed because of multinodular goiter 20 years ago. She was admitted to our clinic and her laboratory results were detected as follows; TSH: $2.81 \mathrm{mUI} / \mathrm{mL}$ (range, 0.55 4.78 ), free T4 (fT4): $2.45 \mathrm{ng} / \mathrm{dL}$ (range, $0.74-1.52$ ), free T3 (fT3): $6.2 \mathrm{pg} / \mathrm{mL}$ (range, 2.3-4.2), anti-thyroglobulin antibody (anti-TG) and anti-thyroperoxidase (anti-TPO) antibody were negative. She had no signs or symptoms of typical thyrotoxicosis. MRI scan did not detect the presence of a pituitary tumor. TSH showed exaggerated response to thyrotropin-releasing hormone and was suppressed following T3 administration. The $\alpha$-subunit of 
TSH was normal (0.76 IU/L, range, $0-1.6)$. The patient also underwent testing for THR $\beta$ gene, which showed a missense mutation in exon $8(\mathrm{~A} 234 \mathrm{D} ; \mathrm{c} .701 \mathrm{C}>\mathrm{A})$. The patient was diagnosed as RTH in the light of laboratory and clinical datas.

Thyroid nodule was palpated on physical examination. Thyroid ultrasonography showed multiple nodules in both lobes. A fine-needle aspiration biopsy (FNAB) was performed and cytological examination showed 'atypical of undetermined significance'. Total thyroidectomy was performed. Pathologic examination revealed papillary thyroid microcarcinoma, tumor size was $0.2 \mathrm{~cm}$ (right lobe). Histologic sections of the tumor tissue are very small so that the BRAF mutation could not be analyzed. As the patient was considered at "very low risk" for an adverse clinical course of her thyroid cancer, ablative doses of radioactive iodine were not administered. Levothyroxine therapy was adjusted and the dose was gradually increased up to $200 \mu \mathrm{g} /$ day. After two months, her TSH level was $84 \mathrm{mUI} / \mathrm{L}$, whereas the fT4 level was $2.33 \mathrm{ng} / \mathrm{dL}$ and she complained for the symptoms of hyperthyroidism; therefore, we decreased the dose of levothyroxine to $175 \mu \mathrm{g} /$ day. After two months her TSH level was $98.76 \mathrm{mUI} / \mathrm{L}$, fT4 level was $1.06 \mathrm{ng} / \mathrm{dL}$ and her symptoms of hyperthyroidism was disappeared.

For to ensure the TSH suppression triiodotironin $50 \mu \mathrm{g} /$ day was added to treatment and levothyroxine was reduced to $150 \mu \mathrm{g} /$ day. After two months TSH level and fT4 level were $23.6 \mathrm{mUI} / \mathrm{L}$ and $1.11 \mathrm{ng} / \mathrm{dL}$, respectively.

\section{Case 2}

A 33-year-old Turkish man was admitted to our clinic because of her mother's RTH and MG disease (case 1). Serum thyroid function tests showed elevated fT4, fT3 and TSH (fT4:1.95 ng/dL, fT3:7.2 pg/mL, TSH: 5.52 $\mathrm{mUI} / \mathrm{L})$. Anti-TG and anti-TPO antibody were negative. He had no signs or symptoms of typical thyrotoxicosis. In such cases, a pituitary tumor (TSHoma) that secreting excess TSH should be excluded from RTH. TSH secreting pituitary adenoma was ruled out because the patient had a normal level of the $\alpha$-subunit of TSH (0.36 IU/L, range, 0-1.6), a negative MRI of the pituitary gland, an exaggerated response of TSH to a thyrotropin-releasing hormone stimulation test and TSH was supressed following T3 administration. There was same mutation in the regions of the THR $\beta$ gene (exon 8; $\mathrm{A} 234 \mathrm{D} ; \mathrm{c} .701 \mathrm{C}>\mathrm{A})$ that was detected in the first case.
Thyroid nodules were detected on physical examination. Ultrasonographic evaluation of the thyroid gland were detected multiple nodules in both lobes. The dominant nodule was $27 \times 42 \times 51 \mathrm{~mm}$ in size in the left lobe and had foci of macrocalcification with mixed echogenicity. Two FNAB was performed and cytological examination resulted as non-diagnostic. The patient underwent total thyroidectomy and papillary thyroid microcarcinoma were detected in two focus with diameters of $0.4 \mathrm{~cm}$ in the left lobe and $0.4 \mathrm{~cm}$ in isthmus. BRAFV600E mutation analysis results were negative from histopathological sections. ${ }^{131}$ radio remnant ablation was performed and after that levothyroxine therapy was initiated and the dose was gradually increased up to $100 \mu \mathrm{g} /$ day. After two months her TSH level and fT4 level were $150 \mathrm{mUI} / \mathrm{L}$ and $1.26 \mathrm{ng} / \mathrm{dL}$ respectively. We increased the dose of levothyroxine to $150 \mu \mathrm{g} /$ day and control appointment arranged for two months later.

\section{DISCUSSION}

RTH has been described by Refetoff in 1967 (10). The cause is mostly mutations in TR $\beta$ gene and inheritance of RTH is autosomal dominant $(1,2)$. Those patients who present with goiter and elevated thyroid hormone levels with unsuppressed TSH must be investigated for RTH. The main differential diagnosis to be excluded is inappropriate TSH secretion from a pituitary tumour (TSHoma). The normal level of the TSH $\alpha$-subunit, a normal MRI of the pituitary gland, an exaggerated response of TSH to a thyrotropin-releasing hormone stimulation test and TSH suppression after T3 administration favour the RTH.

The point mutations in the THR $\beta$ gene are found in about $90 \%$ of RTH cases. Our two cases have same mutations in the regions of the THR $\beta$ gene (exon 8; A234D; c.701C>A). This mutation had not been previously reported as being associated with $\mathrm{RTH}$ in the literature. This is a novel heterozygous missense mutation discovered by our clinic. Also Ünlütürk and cols. from Turkey reported a case of RTH with thyroid cancer which have a single nucleotide substitution $(\mathrm{T}>\mathrm{C})$ in codon 334 in THR $\beta$ gene (11).

PTC is the most common histological type of thyroid malignancy and the rising incidence of thyroid cancer is mainly attributed to the increased diagnosis of PTC, particularly the small micro PTC $(12,13)$. BRAFV600E mutation is the most common genetic alteration in thyroid cancer, and found in about $45 \%$ of papillary thyroid cancers (14). Our in the first case, we 
did not evaluate BRAFV600E mutation because of the small histopathologic cross-sections but in the second case BRAFV600E mutation was negative. High serum TSH levels, typically described in RTH, are associated with increased risk of thyroid malignancy (15). Whereas suppression of TSH levels are recommended as adjunctive treatment in differentiated thyroid cancer (16).

There are case reports related with the association of the RTH and PTC in the literature $(5,6)$. In these cases, clinical euthyroidism with levothyroxine replacement has been achived but TSH suppression was not occured. When the dose of levothyroxine was increased, in those patients hyperthyroidism symptoms (tachycardia, anxiety) occurred, so levothroxine dose was decreased. In two cases, with the addition of T3 to the treatment TSH levels decreased to the normal range $(17,18)$. There are also papers related with suppression of TSH with thyroid hormone analogs, such as triiodothyroacetic acid (TRIAC) in RTH $(19,20)$. TRIAC might be an alternative drug in RTH with DTC to suppress TSH so much peripheral tissue effect.

In conclusion, there are two situation that need to be explained; one of them is whether patients with RTH are at an increased risk for thyroid cancer and the other one is whether thyroid cancer is more aggressive in patients with RTH because of the difficulty in suppressing serum TSH concentration. TSH suppression has been considered as the key step of DTC treatment after total thyroidectomy and radioactive iodine therapy. TSH suppression may not be obtained despite increasing doses of L-T4 in a patient with RTH. There is no consensus on how to overcome the persistently high TSH in patients with RTH and DTC. Further studies are needed to explain the relationship between RTH and DTC which might be helpful for the treatment of these patients.

Disclosure: no potential conflict of interest relevant to this article was reported.

\section{REFERENCES}

1. Refetoff S, Weiss RE, Usala SJ. The syndromes of resistance to thyroid hormone. Endocr Rev. 1993;14(3):348-99.

2. Refetoff S, Dumitrescu AM. Syndromes of reduced sensitivity to thyroid hormone: genetic defects in hormone receptors, cell transporters and deiodination. Best Pract Res Clin Endocrinol Metab. 2007;21(2):277-305.
3. Olateju TO, Vanderpump MP. Thyroid hormone resistance. Ann Clin Biochem. 2006;43(Pt 6):431-40.

4. Barkoff MS, Kocherginsky M, Anselmo J, Weiss RE, Refetoff S. Autoimmunity in patients with resistance to thyroid hormone. $J$ Clin Endocrinol Metab. 2010;95(7):3189-93.

5. Kim HK, Kim D, Yoo EH, Lee Jl, Jang HW, Tan AH, et al. A case of resistance to thyroid hormone with thyroid cancer. J Korean Med Sci. 2010;25(9):1368-71.

6. Paragliola RM, Lovicu RM, Locantore P, Senes P, Concolino P, Capoluongo $E$, et al. Differentiated thyroid cancer in two patients with resistance to thyroid hormone. Thyroid. 2011;21(7):793-7.

7. Tuttle RM, Leboeuf R, Martorella AJ. Papillary thyroid cancer: monitoring and therapy. Endocrinol Metab Clin North Am. 2007;36(3):753-78, vii.

8. Kloos RT. Papillary thyroid cancer: medical management and follow-up. Curr Treat Options Oncol. 2005;6(4):323-38.

9. Hovens GC, Stokkel MP, Kievit J, Corssmit EP, Pereira AM, Romijn $\mathrm{JA}$, et al. Associations of serum thyrotropin concentrations with recurrence and death in differentiated thyroid cancer. J Clin Endocrinol Metab. 2007;92(7):2610-5.

10. Refetoff $S$, DeWind LT, DeGroot LJ. Familial syndrome combining deaf-mutism, stuppled epiphyses, goiter and abnormally high PBI: possible target organ refractoriness to thyroid hormone. J Clin Endocrinol Metab. 1967;27(2):279-94.

11. Ünlütürk U, Sriphrapradang C, Erdogan MF, Emral R, Güldiken S, Refetoff $S$, et al. Management of differentiated thyroid cancer in the presence of resistance to thyroid hormone and TSH-secreting adenomas: a report of four cases and review of the literature. $J$ Clin Endocrinol Metab. 2013;98(6):2210-7.

12. Davies $L$ and Welch $H G$. Increasing incidence of thyroid cancer in the United States, 1973-2002. JAMA 2006; 295: 2164-7.

13. Leenhardt L, Grosclaude P, Chérié-Challine L; Thyroid Cancer Committee. Increased incidence of thyroid carcinoma in france: a true epidemic or thyroid nodule management effects? Report from the French Thyroid Cancer Committee. Thyroid. 2004;14(12):1056-60.

14. Xing M. BRAF mutation in thyroid cancer. Endocr Relat Cancer. 2005;12(2):245-62.

15. Boelaert K, Horacek J, Holder RL, Watkinson JC, Sheppard MC, Franklyn JA. Serum thyrotropin concentration as a novel predictor of malignancy in thyroid nodules investigated by fine-needle aspiration. J Clin Endocrinol Metab. 2006;91(11):4295-301.

16. Maia AL, Ward LS, Carvalho GA, Graf H, Maciel RM, Maciel LM, et al. [Thyroid nodules and differentiated thyroid cancer: Brazilian consensus]. Arq Bras Endocrinol Metabol. Arq Bras Endocrinol Metabol. 2007;51(5):867-93.

17. Weinert LS, Ceolin L, Romitti M, Camargo EG, Maia AL. Is there a role for inheritedTR $\beta$ mutation in human carcinogenesis? [corrected]. Arq Bras Endocrinol Metabol. 2012;56(1):67-71.

18. Taniyama M, Ishikawa N, Momotani N, Ito K, Ban Y. Toxic multinodular goitre in a patient with generalized resistance to thyroid hormone who harbours the R4290 mutation in the thyroid hormone receptor beta gene. Clin Endocrinol (Oxf). 2001;54(1):121-4.

19. TakedaT, Suzuki S, Liu RT, DeGroot LJ. Triiodothyroacetic acid has unique potential for therapy of resistance to thyroid hormone. $J$ Clin Endocrinol Metab. 1995;80(7):2033-40.

20. Radetti G, Persani L, Molinaro G, Mannavola D, Cortelazzi D, Chatterjee VK, et al. Clinical and hormonal outcome after two years of triiodothyroacetic acid treatment in a child with thyroid hormone resistance. Thyroid. 1997;7(5):775-8. 